\title{
Pengetahuan tentang Kanker Payudara dan Pola Konsumsi Isoflavon dari Produk Olahan Kedelai pada Remaja Putri
}

\section{Lely Firrahmawati ${ }^{*}$, Rita Riyanti Kusumadewr', Sri Kustiyat ${ }^{3}$, Irvina Nurul Mahmudah ${ }^{4}$}

\author{
1-3 Dosen Kebidanan Universitas 'Aisyiyah Surakarta \\ 4 Mahasiswa Universitas 'Aisyiyah Surakarta
}

Email korespondensi: lelyaiska@gmail.com

\begin{abstract}
Kanker payudara merupakan sel kanker (tumor malignan) yang tumbuh di dalam epitel duktus atau lobulus pada payudara yang mengalami pertumbuhan abnormal. Isoflavon merupakan komponen yang terdapat dalam kedelai. Senyawa isoflavon bermanfaat bagi kesehatan karena memiliki aktivitas antioksidan yang dapat mencegah kanker payudara. Tujuan penelitian ini adalah ntuk mengetahui gambaran pengetahuan tentang kanker payudara dan gambaran pola konsumsi isoflavon dari produk olahan kedelai pada remaja putri. Desain penelitian ini adalah deskriptif dengan variable pengetahuan tentang kanker payudara dan pola konsumsi isoflavon pada remaja putri. Penelitian ini dilakukan di Desa Jeruk Miri. Populasi dalam penelitian ini adalah seluruh remaja putri di Desa Jeruk Miri yang berjumlah 203 orang dengan teknik pengambilan sampel simple random sampling. Kriteria yang ditetapkan ialah remaja putri usia 10-19 tahun dan bersedia menjadi responden. Pengumpulan data dengan kuesioner dan wawancara selama bulan Februari-April 2019. Analisa yang digunakan adalah univariat. Hasil penelitian menunjukkan distribusi frekuensi berdasarkan usia remaja $</=15$ tahun sebanyak 57 (57\%), usia remaja >15 tahun sebanyak 43 (43\%). Pada penelitian ini sebagian besar responden atau sebanyak 73 (73\%) responden mempunyai tingkat pengetahuan cukup, sebanyak 19 (19\%) responden mempunyai tingkat pengetahuan kurang dan 8 (8\%) responden mempunyai tingkat pengetahuan baik. Dan pada penelitian ini sebagian besar responden atau sebanyak 54 (54\%) responden mengkonsumsi lebih dari $30 \mathrm{mg}$ isoflavon dalam produk olahan kedelai per harinya dan 46 (46\%) responden mengkonsumsi kurang dari $30 \mathrm{mg}$ isoflavon dalam produk olahan kedelai per hari.
\end{abstract}

Keywords : Isoflavon, Kanker Payudara, , Pengetahuan 


\section{PENDAHULUAN}

Disebut kanker payudara ketika sejumlah sel di dalam payudara tumbuh, kehilangan kendali, dan berkembang dengan cepat di dalam jaringan payudara. Kanker Payudara (Carcinoma mammae) merupakan salah satu kanker yang sangat ditakuti oleh kaum wanita, setelah kanker serviks. (Miller et al., 2016)

Jadi, kanker payudara itu pada prinsipnya adalah tumor ganas yang berasal dari kelenjar kulit, saluran kelenjar, dan jaringan di sebelah luar rongga dada. Dimana, payudara secara umum terdiri dari dua tipe jaringan, jaringan glandular (kelenjar) dan jaringan stromal (penopang). Sel kanker payudara dapat bersembunyi di dalam tubuh selama bertahun-tahun tanpa diketahui dan tiba-tiba aktif menjadi tumor ganas atau kanker.(Miller et al., 2016)

Menurut (Purbasari \& Septiannisaa, 2020), gejala yang dapat diamati atau dirasakan oleh orang yang terkena penyakit kanker payudara, antara lain :
a. Munculnya benjolan tidak normal
b. Pembengkakan
C. Rasa nyeri di bagian puting
d. Pembengkakan kelenjar getah bening
e. Keluar cairan aneh di puting
f. Putih tenggelam (nipple retraction)

Tanda dan gejala berdasarkan fase kanker payudara yaitu sebagai berikut :

a. Fase awal

Pada fase awal kanker payudara asimptomatik (tanpa tanda dan gejala).Tanda dan gejala yang paling umum yaitu adanya benjolan dan penebalan payudara. Sekitar $90 \%$ tanda dan gejalanya ditemukan oleh penderita sendiri, dan pada stadium dini kanker payudara tidak menimbulkan keluhan.

b. Fase lanjut

Bentuk dan ukuran payudara mulai berubah, berbeda dari sebelumnya. Luka pada payudara tidak kunjung sembuh walaupun sudah diobati, eksim pada puting susu dan sekitarnya tidak kunjung sembuh. Puting susu terasa sakit, keluar darah, nanah ataupun cairan encer dari puting atau air susu pada wanita yang sedang hamil atau tidak menyusui, puting susu tertarik masuk kedalam serta kulit payudara mengerut seperti kulit jeruk. 


\section{c. Metastase luas}

Pembesaran kelenjar getah bening supraklavikula dan servikal. Hasil rontgen thorak abnormal dengan atau tanpa efusipleura. Peningkatan alkali fosfatase atau nyeri tulang berkaitan dengan penyebarannya sudah sampai ke tulang. (Hutapea, 2017)

Sampai saat ini belum diketahui secara pasti penyebab kanker payudara, diperkirakan multifaktor yaitu banyak faktor yang saling terkait satu sama lain untuk mempengaruhi terjadinya kanker payudara. Ada beberapa faktor kemungkinannya yang terdiri dari faktor risiko yang tidak dapat diubah (unchangeable) dan dapat diubah (changeable), yaitu :

a. Faktor resiko kanker payudara yang tidak dapat diubah, antara lain :

1. Jenis kelamin, dimana wanita berpotensi lebih besar terkena kanker payudara dibandigkan pria.

2. Usia, dimana angka kejadian kanker payudara meningkat seiring dengan bertambahnya usia. Angka kejadian meningkat pada wanita berusia diatas 30 tahun. Akan tetapi angka rata-rata kejadian kanker payudara terjadi pada wanita dengan usia 60 tahun.

3. Faktor genetik, hal ini didorong oleh kecenderungan familial yang kuat. Sekitar 5-10\% dari kanker payudara terjadi akibat adanya kelainan genetik yang diturunkan oleh anggota keluarga.

4. Wanita yang mengalami menstruasi sebelum usia 12 tahun dan memiliki siklus menstruasi yang panjang (permulaan menstruasi cepat tetapi menopause lambat terjadi).

5. Wanita yang pernah mendapatkan terapi radiasi pada organ dada termasuk payudara sebelum usia 30 tahun atau secara intensif mendapatkan terapi radiasi. Misalkan pada penderita tubercolusis atau kanker lain, diketahui bisa meningkatkan resiko terkena kanker payudara.

b. Faktor resiko kanker payudara yang dapat diubah, antara lain:

1. Wanita yang tidak pernah mengalami kehamilan sehigga tidak memiliki anak dan melahirkan diatas usia 30 tahun memiliki potensi lebih besar terkena kanker payudara.

2. Wanita yang mengonkumsi alkohol memiliki resiko lebih rentan terkena kanker payudara pada tahun-tahun terakhirnya.

3. Wanita yang mengkonsumsi makanan dengan lemak tinggi dan wanita yang memiliki berat badan lebih (obesitas) lebih sering terkena kanker payudara. (Purbasari \& Septiannisaa, 2020) 
Jenis- jenis kanker payudara antara lain:

a. Tumor Jinak (Fibroadenoma Mamae):

Tumor jinak ini berkembang di jaringan dan kelenjar susu.

b. LCIS (Lobular Carcinoma In Situ):

LCIS ini tidak meluas tetapi hanya terjebak pada kelenjar susu.

C. DCIS (Ductal Carcinoma In Situ):

DCIS adalah perkembangan sel abnormal yang menyerang sel- sel pada saluran susu.

d. ILC (Infiltrating Lobular Carcinoma):

Kanker jenis ini menyerang jaringan payudara di bawah kulit, di dalam kelenjar susu dan menyebar ke jaringan lemak serta jaringan penyangga payudara.

e. IDC (Infiltrating Ductal Carcinoma):

Jenis kanker ini paling banyak menyerang. IDC berawal dari saluran susu dan menyebar melalui aliran sarahserta jaringan limfa ke bagian tubuh lainnya.(Hutapea, 2017)

Pengobatan pada pasien kanker payudara ada beberapa jenis dan salah satunya adalah kemoterapi. Kemoterapi merupakan penggunaan obat-obatan khusus untuk mematikan sel-sel kanker. Efek samping yang akan muncul pada kemoterapi tergantung pada jumlah obat yang didapatkan, masa pengobatan dan keadaan kesehatan umum penderita. Efek kemoterapi yang paling umum terjadi seperti mual, muntah, kelelahan, anemia, diare, rambut rontok, infeksi, infertil, masalah kesuburan dan perubahan berat badan. (Nurhikmah et al., 2018)

Menurut(Hutapea, 2017) pencegahan untuk menangani masalah kanker payudara dapat dilakukan melalui pencegahan primer, sekunder maupun tersier.

a. Pencegahan primer

Pencegahan primer adalah pencegahan yang paling utama. Caranya adalah dengan upaya menghindarkan diri dari keterpaparan pada berbagai faktor resiko dan melaksanakan pola hidup sehat. Cara ini dilakukan oleh para wanita yang belum sama sekali terdeteksi adanya kanker payudara. Hal ini sangat bagus bila dilakukan, sebab dapat mencegah kanker payudara secara dini

b. Pencegahan sekunder

Terkadang kita tidak tau bahwa kita dapat terkena resiko kanker payudara. Dari pola makan yang salah atau dari riwayat keluarga yang pernah menderita kanker ini. Pencegahan sekunder merupakan pencegahan yang dilakukan terhadap individu yang memiliki resiko 
untuk terkena kanker payudara. Pencegahan sekunder dilakukan dengan melakukan deteksi dini melalui beberapa metode seperti mamografi atau periksa payudara sendiri (SADARI).

c. Pencegahan tersier

Pencegahan tersier yang dilakukan lebih diarahkan kepada individu yang telahpositif menderita kanker payudara. Penanganan yang tepat pada kanker payudara disesuaikan dengan stadiumnya agar dapat mengurangi kecacatan dan memperpanjang harapan hidup penderita. Pencegahan tersier bertujuan untuk meningkatkan kualitas hidup penderita serta mencegah komplikasi penyakit dan meneruskan pengobatan.

Kedelai potensial sebagai bahan pangan fungsional,di samping sebagai sumber protein. Hal ini berkaitan dengan keberadaan 12 jenis isoflavon pada bijikedelai, baik dalam bentuk glikosida maupun aglikon. Kandungan isoflavon pada biji kedelai bervariasi dari 128 hingga 380 $\mathrm{mg} / 100 \mathrm{~g}$, dan yang dominan adalah genistein dan daidzein. (Yulifianti et al., 2018)

Isoflavon merupakan senyawa metabolit sekunder yang dengan kemampuan antioksidannya dapat menghambat aktivitas enzim penyebab kanker (anti kanker), di antaranya kanker payudara, kanker prostat dan kanker kolon. Isoflavon terdapat pada banyak spesies tanaman, tetapi tanaman kacang-kacangan, terutama kedelai mempunyai kandungan isoflavon tertinggi. (Yulifianti et al., 2018)

Isoflavon merupakan senyawa metabolit sekunder yang banyak disintesis oleh tanaman, namun tidak disintesis oleh mikroorganisme. Oleh karena itu, kedelai merupakan sumber utama senyawa isoflavon di alam. Di antara berbagai tanaman, kandungan isoflavon yang lebih tinggi terdapat pada tanaman Leguminoceae, khususnya pada tanaman kedelai. Pada tanaman ini, kandungan isoflavon yang lebih tinggi terdapat pada biji, khususnya pada bagian kotiledon yang akan tumbuh menjadi tanaman,sebagian lagi terdapat pada kotiledon yang akan menjadi daun pertama tanaman, namun jumlah dan komposisinya bervariasi, bergantung pada bagian morfologi biji (kotiledon, hipokotil, dan integument), genotipe, dan daerah geografis budidaya.(Krisnawati, 2017)

Genistein merupakan senyawa yang berperan penting dalam pembentukan maupun penghambatan aktivitas sel tumor/kanker. Terdapat hubungan antara penggunaan isoflavon dengan pengurangan risiko serangan kanker payudara. Isoflavon genistein dan daidzein dari kedelai telah digunakan sebagai obat pencegahan kanker payudara dengan dosis harian $50 \mathrm{mg}$, setara dengan sekitar 50 g produk kedelai. (Krisnawati, 2017) 
Isoflavon dalam olahan kedelai dipercaya dapat meningkatkan produksi ASI, mengurangi resiko kanker payudara, meningkatkan pembelahan sel-sel payudara, menekan pertumbuhan sel-sel tumor, dan mekanisme yang lainnya. Ibu yang mengkonsumsi bahan makanan yang terbuat dari kedelai baik berupa susu kedelai dan olahan kedelai lainnya diyakini dapat meningkatkan kadar isoflavon dalam jaringan di payudara. Kedelai jika dikonsumsi secara rutin bisa berefek baik untuk kesehatan yaitu mencegah terjadinya kanker payudara. (Puspitasari, 2018)

\section{METODE}

Desain penelitian ini adalah deskriptif dengan variable pengetahuan tentang kanker payudara dan pola konsumsi isoflavon pada remaja putri. Penelitian ini dilakukan di Desa Jeruk Miri. Populasi dalam penelitian ini adalah seluruh remaja putri di Desa Jeruk Miri yang berjumlah 203 orang dengan teknik pengambilan sampel simple random sampling.

Kriteria yang ditetapkan ialah remaja putri usia 10-19 tahun dan bersedia menjadi responden. Peneliti mengambil sampel 100 remaja putri dari populasi sebanyak 203 remaja putri. Peneliti membuat daftar remaja putri lalu melakukan undian terhadap 203 remaja putri dan mengambil sebanyak 100 remaja putri untuk dijadikan sampel. Pengumpulan data dengan kuesioner dan wawancara selama bulan Februari-April 2019. Analisa yang digunakan adalah univariat.

\section{HASIL DAN PEMBAHASAN}

a. Gambaran Usia

Menurut penelitian yang dilakukan(Purbasari \& Septiannisaa, 2020), peningkatan usia merupakan factor resiko terjadinya kanker payudara. Berdasarkan hasil penelitian usia remaja <l= 15 tahun sebanyak 57 (57\%) responden, usia remaja >15 tahun sebanyak 43 (43\%) responden. Target untuk menaggulangi terjadinya kanker payudara pada wanita dapat dicegah saat masih remaja, karena remaja merupakan kelompok rentan terkena kanker payudara. SADARI perlu dilakukan karena seiring berjalannya waktu, penyakit ini mulai mengarah ke usia lebih muda. (Kusumawaty et al., 2021)

b. Gambaran Tingkat Pengetahuan Responden Tentang Kanker Payudara

Pengetahuan diperlukan sebagai dukungan dalam menimbulkan rasa percaya diri maupun sikap dan perilaku setiap hari, sehingga dapat dikatakan bahwa pengetahuan merupakan domain yang sangat penting untuk terbentuknya tindakan seseorang.

Hasil penelitian ini diperoleh 73 (73\%) responden mempunyai tingkat pengetahuan 
cukup, sebanyak 19 (19\%) responden mempunyai tingkat pengetahuan kurang dan 8 (8\%) responden mempunyai tingkat pengetahuan baik. Hasil penelitian tersebut menggambarkan bahwa pengetahuan remaja dalam kategori baik hanya 8 (8\%) responden. Tingginya tingkat pengetahuan remaja mengenai kanker payudara dan pencegahannya dapat juga dipengaruhi juga oleh factor pengalaman dan fasilitas yang tersedia.

Pendekatan edukasi berupa pendidikan kesehatan akan lebih tepat digunakan untuk pembinaan dan peningkatan kesehatan karena dapat meningkatkan pengetahuan dan kesadaran tentang kesehatannya. Peran bidan dalam hal ini sangat diperlukan dalam upaya pencegahan terhadap kanker payudara melalui edukasi tentang kanker payudara

c. Gambaran Pola Konsumsi Isoflavon per Hari dalam Produk Olahan Kedelai

Prinsip pencegahan primer kanker payudara adalah dengan mencegah sedini mungkin diantaranya dengan mengkonsumsi isovlavon per harinya 30-40 mg. Menurut (Puspitasari, 2018) konsumsi dari isoflavon dari kedelai dapat mencegah risiko kanker payudara.

Hasil penelitian menunjukkan sebagian besar responden atau sebanyak 54 (54\%) responden mengkonsumsi lebih dari $30 \mathrm{mg}$ isoflavon dalam produk olahan kedelai per harinya dan sebanyak 46 (46\%) responden mengkonsumsi kurang dari $30 \mathrm{mg}$ isoflavon dalam produk olahan kedelai per hari. Sehingga disimpulkan bahwa konsumsi isoflavon resonden mencukupi kebutuhan.

\section{KESIMPULAN}

Berdasarkan hasil penelitian yang telah dilakukan di Desa Jeruk Kecamatan Miri Kabupaten Sragen maka dapat disimpulkan sebagai berikut :

1. Hasil penelitian ini menunjukkan usia remaja $</=15$ tahun sebanyak 57 (57\%) responden, usia remaja >15 tahun sebanyak 43 (43\%) responden. Gambaran tingkat pengetahuan responden tentang kanker payudara

2. Gambaran tingkat pengetahuan responden tentang kanker payudara dari hasil penelitian ini diperoleh 73 (73\%) responden mempunyai tingkat pengetahuan cukup, sebanyak 19 (19\%) responden mempunyai tingkat pengetahuan kurang dan 8 (8\%) responden mempunyai tingkat pengetahuan baik. Hasil penelitian tersebut menggambarkan bahwa pengetahuan remaja dalam kategori baik hanya $8(8 \%)$ responden.

Gambaran pola konsumsi isoflavon dalam produk olahan kedelai sudah cukup per harinya. Hasil 
penelitian menunjukkan sebagian besar responden atau sebanyak 54 (54\%) responden mengkonsumsi lebih dari $30 \mathrm{mg}$ isoflavon dalam produk olahan kedelai per harinya dan sebanyak 46 (46\%) responden mengkonsumsi kurang dari $30 \mathrm{mg}$ isoflavon dalam produk olahan kedelai per hari.

\section{DAFTAR PUSTAKA}

Hutapea, M. (2017). Pengaruh Pelaksanaan Pemeriksaan Payudara Sendiri (Sadari) Terhadap Pengetahuan Dan Kemampuan Siswi Dalam Upaya Deteksi Dini Kanker Payudara Sma Swakarya Tahun 2017. Jurnal Riset Hesti Medan Akper Kesdam I/BB Medan, 2(2), 105. https://doi.org/10.34008/jurhesti.v2i2.77

Krisnawati, A. (2017). Soybean as Source of Functional Food. Iptek Tanaman Pangan, 12(1), 57-65. Kusumawaty, J., Noviati, E., Sukmawati, I., Srinayanti, Y., \& Rahayu, Y. (2021). Efektivitas Edukasi SADARI (Pemeriksaan Payudara Sendiri) Untuk Deteksi Dini Kanker Payudara. ABDIMAS: Jurnal Pengabdian Masyarakat, 4(1), 496-501. https://doi.org/10.35568/abdimas.v4i1.1177

Miller, K. D., Siegel, R. L., Lin, C. C., Mariotto, A. B., Kramer, J. L., Rowland, J. H., Stein, K. D., Alteri, R., \& Jemal, A. (2016). Cancer treatment and survivorship statistics, 2016. CA: A Cancer Journal for Clinicians, 66(4), 271-289. https://doi.org/10.3322/caac.21349

Nurhikmah, W., Wakhid, A., \& Rosalina, R. (2018). Hubungan Mekanisme Koping Dengan Kualitas Hidup Pada Pasien Kanker Payudara. Jurnal Ilmu Keperawatan Jiwa, 1(1), 38. https://doi.org/10.32584/jikj.v1i1.35

Purbasari, S., \& Septiannisaa, E. (2020). PERANCANGAN BOOKLET MENGENAI PROGRAM PERIKSA PAYUDARASENDIRI ( SADARI) SEBAGAI MEDIA KAMPANYE UNTUK PELAJAR REMAJA PUTRI SEKOLAH MENENGAH PERTAMA DI KOTA. 03(02), 207-230.

Puspitasari, E. (2018). Pengaruh Pemberian Susu Kedelai Terhadap Peningkatan Produksi Asi Pada Ibu Nifas Di Rb Bina Sehat Bantul the Influence of Soybean Milk Is on Increasing the Production of Asi Materials in the Nifas Mother in Rb Bina Healthy Bantul. Jurnal Kebidanan, 7(1), 54-60.

Yulifianti, R., Muzaiyanah, S., \& Utomo, J. S. (2018). Soybean as High Isoflavones content Food (Original title in Indonesian: Kedelai sebagai Bahan Pangan Kaya Isoflavon). Buletin Palawija, 16(2), 84 . 